\title{
Socioeconomic Factors Drive Fire-Regime Variability in the Mediterranean Basin
}

\author{
Brahim Chergui, ${ }^{1}$ Soumia Fahd, ${ }^{1}$ Xavier Santos, ${ }^{2}$ and Juli G. Pausas ${ }^{3 *}$
}

\begin{abstract}
${ }^{1}$ Laboratoire Ecologie, Biodiversité et Environnement, Faculté des Sciences de Tétouan, Université Abdelmalek Essaâdi, El M'Hannech, BP 2121, Té touan, Morocco; ${ }^{2}$ CIBIO/InBIO (Centro de Investigação em Biodiversidade e Recursos Gené ticos da Universidade do Porto)., R. Padre Armando Quintas, 4485-661 Vairão, Portugal; ${ }^{3}$ CIDE-CSIC, Campus IVIA, CV-315, Km 10.7, 46113 Montcada, Valencia, Spain
\end{abstract}

\begin{abstract}
In recent decades, fires in Mediterranean Europe have become larger and more frequent. This trend has been driven by socioeconomic changes that have generated rural depopulation and changes in traditional land use. Within the Mediterranean Basin, the most contrasting socioeconomic conditions are found by comparing southern European with North African countries, and thus our hypothesis is that this difference generates contrasting fire regimes between the two regions. Specifically, we predict that current fire regimes in Mediterranean Africa resemble past fire regimes in the Mediterranean Europe when rural activities dominated the landscape. To test our hypothesis, we compared fire statistics from the western Rif (northern Morocco, 1988-2015) and from Valencia (eastern Spain, 1880-2014). The results suggest that the Rif has a typical Mediterranean fire regime with fires occurring in the hot, dry summer season. However, fires are very small and the annual pro-
\end{abstract}

The final version will be published in Ecosystems (2018),

http://dx.doi.org/10.1007/s10021-017-0172-6

Author contributions: XS and JGP conceived of the idea; BCH and JGP collected the data; $\mathrm{BCH}, \mathrm{XS}$, and JGP analysed the data; and all the authors contributed to the writing.

*Corresponding author; e-mail: juli.g.pausas@ext.uv.es;

URL: http://www.uv.es/jgpausas/ portion of burnt area is very low, compared to the current regime in Valencia (post-1970s). The current Rif fire size class distribution matches the fire regime in Valencia prior to the 1970s before the collapse of the rural population and when fires were fuel-limited. The shift in the recent decades in fire regime observed in different countries of the Mediterranean Europe (from small, fuel-limited fires to drought-driven fires) can be identified when moving from the southern to the northern rim of the basin. That is, most spatial and temporal variability in fire regimes of the Mediterranean Basin is driven by shifts in the amounts of fuel and continuity imposed by changes in socioeconomic drivers.

Key words: Western Mediterranean; Fire regime; Fire and climate; Fuel amount; Rural abandonment; Area burnt; Socioeconomic drivers; Land-use changes; Morocco; Spain.

\section{INTRODUCTION}

The diversity of fire regimes, that is, the combinations of frequency, intensity, seasonality, and fire spread pattern, is one of the most important factors determining the structure of the landscape in many ecosystems (Bond and others 2005; Keeley and others 2012; Pausas and Ribeiro 2013). Fire regimes, however, can change. Historically, shifts in fire regimes were related mainly to changes in 
atmospheric $\mathrm{O}_{2}$ concentration, climate oscillation, and abrupt herbivore extinctions (McKenzie and others 2004; Gil and others 2009; Pausas and Keeley 2009, 2014). More recently, shifts in human activities have been interacting with climate to alter fire regimes (Marlon and others 2008; Bowman and others 2011). Human activities have changed ignition patterns (Keeley 2002; Keeley and others 2012), and anthropogenic climate changes have increased the conditions conducive to fire and thus modified fire frequency and fire seasonality (Piñol and others 1998; Kasischke and Turetsky 2006; Swetnam 1993; Westerling and others 2006; Pezzatti and others 2013). However, the most important human shifts in relation to fire are fuel amount and structure, and these are driven by land-use and land management changes (Covington and Moore 1994; Dubinin and others 2011; Pausas and Fernández-Muñoz 2012; Moreira and Russo 2007; Pausas and Keeley 2014).

The Mediterranean Basin (defined here as the region around the Mediterranean Sea with a Mediterranean-type climate) has an annual dry and warm period (summer) when intense crown fires are frequent (Pausas and Vallejo 1999; Pausas 2004; Keeley and others 2012). In such ecosystems, fire controls the age and structure of the vegetation, as well as the composition of species (Verdú and Pausas 2007), that is, vegetation depends not only on climate, but also on the fire regime (Trabaud 1996; Keeley and others 2012), and human activities have strongly modulated fire regimes across the Mediterranean Basin (Pausas and Vallejo 1999; Keeley and others 2012). The first evidence of fire-regime changes induced by humans in the Mediterranean Basin dates to the Neolithic (Naveh 1975). Since then, the Mediterranean has witnessed the evolution of many cultures, some with high population densities that have altered fire regimes in different directions (Keeley and others 2012). There is overwhelming evidence that the main driver for recent fire activity in Mediterranean Europe is associated with land-use changes and ultimately socioeconomic changes (Pausas 2004; Moreira and others 2011; Pausas and Paula 2012; Salis and others 2013). Rural depopulation and consequent land abandonment, together with reforestation projects, have caused an increase in the amount and connectivity of fuels, and this switched fire regimes from fuel-limited (during the dominance of rural lifestyles) to the current drought-driven fire regimes (that is, large fires driven by droughts; Pausas and Ferná ndez-Muñoz 2012). However, because the socioeconomic levels are not homogeneous throughout the Mediter- ranean Basin (Zohry 2005), land use and fire regimes are expected to covary across the region. The most contrasting socioeconomic difference within the Mediterranean Basin lies between European and North African rim of the basin (Mairota and others 1998). Mediterranean Europe is strongly industrialized, and rural depopulation has increased the amount of landscape fuel and connectivity, whereas Mediterranean North Africa has a lower level of industrial activity and higher rural population densities. Agricultural activities, wood gathering, and especially overgrazing (mainly by goats and sheep) in many North African landscapes (Taiqui and Martin 1997) are drastically reducing fuel amounts and potentially influencing the fire regime. We therefore expect a strong spatial variability in fire regime within the biogeographic region of the Mediterranean Basin.

Unfortunately, little is known about fire regimes in North Africa, partially because of the paucity of fire statistics (but see Meddour-Sahar and others 2013b; Mharzi Alaoui and others 2015). Our hypothesis is that current fire regimes in Mediterranean Africa resemble past fire regimes in the Mediterranean Europe when rural activities dominated the landscape. If this is true, then we would have clues for predicting future fire regimes in North Africa, based on trends in southern Europe, and for understanding past fire regimes in Europe based on the current situation in North Africa. Specifically it would provide independent evidence for the role of socioeconomic factors in fire regime across the Mediterranean Basin ecosystems. Alternatively, similarity in current fire activity between the Mediterranean Europe and Mediterranean Africa would indicate that other factors such as climate were more important drivers of fire regimes than socioeconomic (and fuel) changes.

To test our hypothesis, we first studied the current fire regimes in the western Rif (northern Morocco in North Africa; hereafter, the Rif) and then we made a comparison with historical and current fire activity in the province of Valencia (Spain in southern Europe) where fire statistics are available from the end of the nineteenth century (Pausas and Ferná ndez-Muñ oz 2012). In Valencia, fire regimes shifted around the 1970s, and thus, we compared the fire regime of the Rif with the Valencia fire regime before the 1970s (when agriculture and livestock were the main economic activities in Spain), and after 1970s (when rural areas lost population as a consequence of the people moving to the secondary and tertiary sector) (Pausas and Ferná ndez-Muñ oz 2012). The Rif and Valencia lie in the same biogeographic region, 
share climate and vegetation types (Mediterranean), but differ strongly in their socioeconomic dynamics, thus providing an excellent model to test the sensitivity of fire regimes to different socioeconomic frameworks.

\section{MetHods}

\section{Study Areas}

The Rif stretches across part of northern Morocco, with the Atlantic Ocean to the west, the Mediterranean Sea to the east, and the Strait of Gibraltar to the north (Fig. 1). The climate is mainly Mediterranean (Table 1) with a mean annual temperature ranging from $15-19^{\circ} \mathrm{C}$ (Ajbilou 2001) and an annual rainfall that can reach $2000 \mathrm{~mm}$ (average values in Table 1). A clear altitudinal gradient in the Rif, from the coast and valleys to uplands (the maximum altitude is $2159 \mathrm{~m}$ at Jbel Lakraa), defines different bioclimatic zones (Qué zel and Médail 2003): the thermo-Mediterranean zone (widespread, from 0 to $900 \mathrm{~m}$; with temperature of the coldest month between 3 and $7^{\circ} \mathrm{C}$ ), the mesoMediterranean zone (between 900 and $1450 \mathrm{~m}$; mean temperature of the coldest month between 0 and $3^{\circ} \mathrm{C}$ ), the supra-Mediterranean zone (between 1450 and $1800 \mathrm{~m}$; mean temperature of the coldest month between 0 and $-3^{\circ} \mathrm{C}$ ), and a small zone over $1800 \mathrm{~m}$ (mean temperature of the coldest month of the year -3 and $-7^{\circ} \mathrm{C}$ ).

The province of Valencia, in eastern Spain, is bordered by the Mediterranean Sea on the east (Figure 1). The climate is typically Mediterranean with mild winters and warm dry summers. A clear altitudinal gradient, from sea level to $1837 \mathrm{~m}$ (Pico Calderón), results in different bioclimatic zones: the thermo-Mediterranean zone (see above for the definition based on the temperature of the coldest month) along the coast, the meso-Mediterranean zone inland, and a small supra-Mediterranean area further inland in the north-western mountains. Most of the area is dry (annual precipitation from 350 to $600 \mathrm{~mm}$ ) and sub-humid (from 600 to $1000 \mathrm{~mm}$ ) (Table 1).

The population density of the two areas is similar (Table 1) but with sharply different in distribution. In the Rif, 37\% of the population live in rural areas and small towns (Mikesell 1960; Taiqui and Martin 1997; Figure S1 in Supporting Information); forests are heavily exploited for timber and fuel by a dense

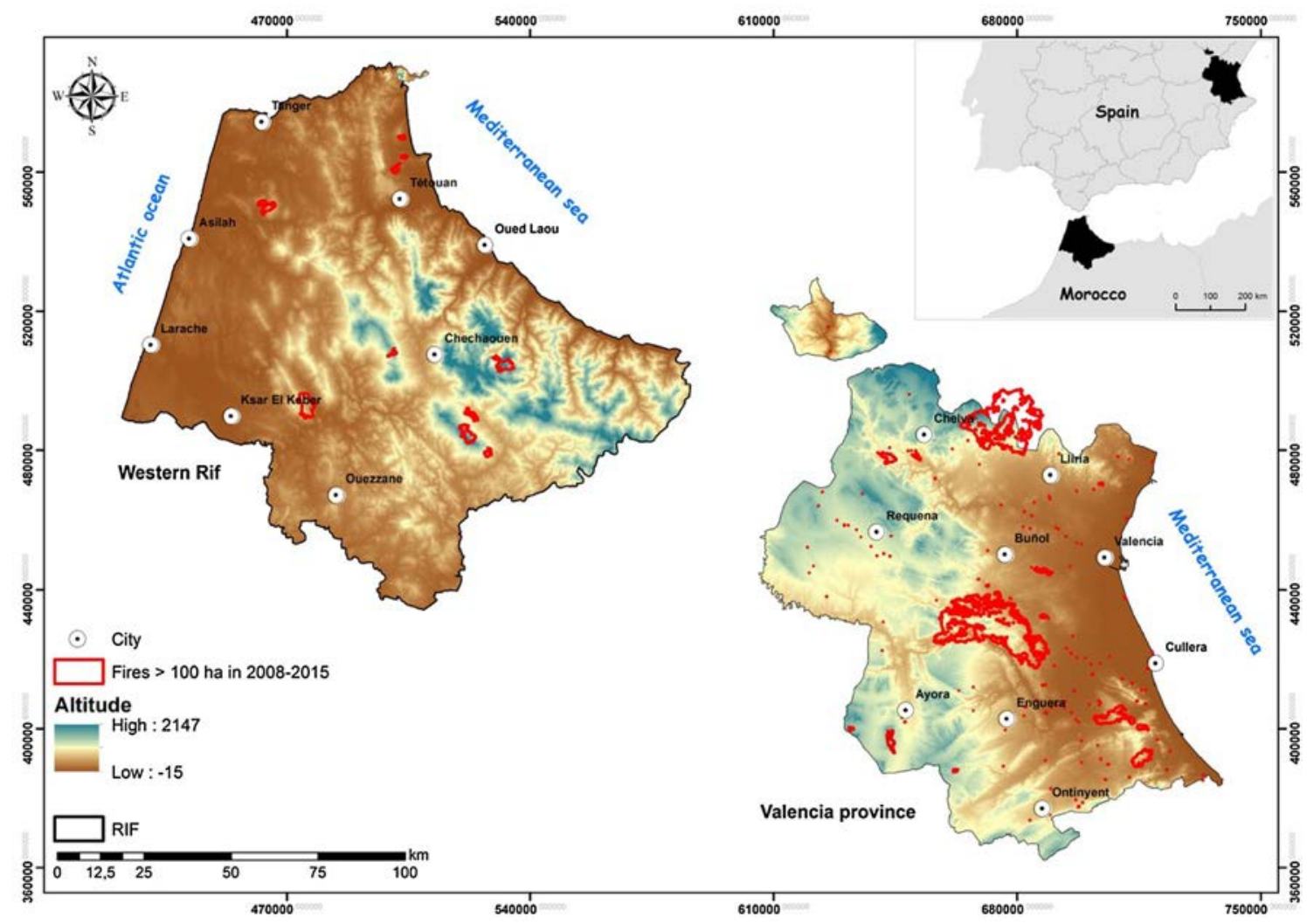

Figure 1. Location of the two study areas in the Rif and Valencia (right top corner), and their topography, with fires larger than 100 ha during the period 2008-2015. 
Table 1. Summary of the Geographic, Climatic, and Socioeconomic Variables for the Two Study Areas.

\begin{tabular}{lll}
\hline & Western Rif & Valencia \\
\hline Geography & & $39.98 / 38.69$ \\
$\quad$ Latitude (range) & $35.84 / 34.54$ & $-1.13 /-0.60$ \\
Longitude (range) & $-5.58 /-5.25$ & 10,763 \\
Size $\left(\mathrm{km}^{2}\right)$ & 12,650 & 53 \\
Wildland area (\%) & 35 & $16.2(n=94)$ \\
Climate & & $532(n=56)$ \\
Mean annual temperature ( $n=$ stations) & $18.44(n=6)$ & 19 \\
Total annual precipitation $(n=$ stations) & $639(n=30)$ & $2,566,474$ \\
Summer precipitation (\%) & 1.8 & 2.38 \\
Demography and socioeconomics & $3,157,075$ & $50(1950) 6.1(2001)$ \\
Total current population & 2.50 & $0.15(2001)$ \\
Population density (inhabitants/ha) & $44(1994) 37(2014)$ & 3.5 \\
Rural population (\%, year) & $0.92(2014)$ & 22.9 \\
Rural population density (inhab./ha) & 44 & 73.6 \\
Employment (\%) by sector (primary, secondary & 22.5 & 2.1 \\
and services) in 2013 & 33.5 & 27.8 \\
Gross Domestic Product (\%) by sector (primary, secondary & 12.2 & 70.1
\end{tabular}

Average values of climatic variables are based on a number of meteorological stations (in brackets). Sources for the socioeconomic data: www.hcp.ma, www.pegv.gva.es, Pausas and Fernández-Muñoz (2012).

rural population and are grazed by goats, cows, and sheep (with some 200,000 goats, 216,000 sheep, and 105,000 cows; Ajbilou 2001). In Valencia, the current rural population is 6.5\% (2001) despite being 50\% in 1950 and 70\% in 1900 (Pausas and Fernández-Muñoz 2012); and currently, sheep, goats, and cows are rare and raised and fed mainly inside farms, with very little open grazing. This is reflected in the statistics by socioeconomic sector: most people in Valencia work in the service sectors, whereas most people in the Rif work in the primary sector (Table 1 ).

The vegetation of the two areas is dominated by Mediterranean evergreen forests and shrubland. In the Rif, cork oak (Quercus suber) forests and shrublands are the dominant formations, followed by holm oak (Quercus ilex) and maritime pine (Pinus pinaster) forests. Vegetation in Valencia is dominated by Aleppo pine (Pinus halepensis) with some holm oak woodlands, and a diversity of shrublands; cork oak and maritime pine are also present but uncommon.

\section{Forest Fire Database for the Western Rif}

The Rif is the region with the highest fire incidence in Morocco (Schmuck and others 2012). To characterize the fire regime of the western Rif, we used two different data sets differing in data quality and temporal window. (1) Information about the annual area burnt and number of fires from 1988 to 2015, taken from the Haut Commissariat aux Eaux et Fore'ts et a' la Lutte Contre la De'sertification (hereafter the HCEFLCD), the École Nationale Forestière d'Inge'nieurs (hereafter ENFI), and from Mharzi Alaoui and others (2015). (2) For the period 2008-2015, the available data are much more detailed and include the specific dates, coordinates of the ignition point, and size of all recorded fires (Figure S2). This data set was acquired from the HCEFLCD plus grey information from historic documents and reports, dossiers on fires, and local newspapers. Coordinates of all ignition points for the period 2008-2015 were intersected with four ecogeographical variables (mean annual rainfall, average maximum temperature, bioclimatic type, and land-use type) using GIS tools (ArcView version 10.0; ESRI, Redlands, CA, USA). Climatic variables (mean annual rainfall and average maximum temperature) were taken from the Climatology Resource for Agroclimatology (https://power.larc.nasa.gov/cgi-bin/agro.cgi), whereas the land-use distribution was determined from the National Forest Inventory. The initial land-use classification was reclassified into eight land-use classes as follows: natural forests (four types: Quercus suber, Quercus rotundifolia, Pinus pinaster, and other natural forests); shrublands; 
Table 2. Summary of the Trends (Expressed as Slope of the Regression, with Their SE and $P$ value) in Number of Fires, Area Burnt, and Climate for the Rif (1988-2015) and Valencia (post-70»s).

\begin{tabular}{llcc}
\hline$X$ & Y & Western Rif & Valencia \\
\hline Time & Area burnt & $-2.60 \pm 37.8$ (n.s.) & $+0.59 \pm 0.8(\mathrm{n} . \mathrm{s})$. \\
Time & Number of fires & $+3.33 \pm 1.4(0.026)$ & $+10.0 \pm 4.1(0.02)$ \\
Time & Annual P & $-7.17 \pm 5.7(\mathrm{n} . \mathrm{s})$. & $-0.56 \pm 4.4(\mathrm{n} . \mathrm{s})$. \\
Time & Summer P & $-0.33 \pm 0.3(\mathrm{n} . \mathrm{s})$. & $-0.52 \pm 0.3(\mathrm{n} . \mathrm{s})$. \\
Time & Annual T & $+0.07 \pm 0.01(<0.0001)$ & $+0.035 \pm 0.01(0.0007)$ \\
Time & Summer T & $+0.12 \pm 0.02(<0.0001)$ & $+0.05 \pm 0.02(0.01)$ \\
Annual P & Area burnt & $-2.43 \pm 1.2(0.05)$ & $-0.08 \pm 0.04(0.03)$ \\
Summer P & Area burnt & $-3.86 \pm 20.2$ (n.s.) & $-0.46 \pm 0.17(0.01)$ \\
Annual T & Area burnt & $+30.55 \pm 433$ (n.s.) & $-2.3 \pm 12.5(\mathrm{~ns})$
\end{tabular}

$Y$ and $X$ refer to the dependent and the independent variable of the regression. P precipitation; T temperature (mean maximum for Rif, and mean annual for Valencia). Valencia information from Pausas (2004); more details for the Rif in the Supplementary Material (S4-S7). n.s. indicates a non-significant slope.

coniferous plantations (especially P. pinaster); other monocultures; and non-forested land uses (agricultural fields and urbanized areas). Four bioclimatic types are represented in the study area, namely perhumid, humid, semi-humid, and semiarid (Benabid 1982; Mharzi Alaoui and others 2015; Figure S2).

\section{Data Analyses}

For the Rif, we first tested whether there was any trend in the fire history during the study period using annual fire data (burnt area and number of fires), and whether the temporal variability in annual fires was linked to climate variability (mean annual rainfall and average maximum temperature). We also tested the spatial distribution of fires in relation to the bioclimate and land-use types using the Chi-squared test with the expected frequencies under a null model (that is, the fire activity was similar in each bioclimate and land-use type).

For Valencia, we considered the number of fires and burnt area for the period 1880-2014 from an updated version (8 years added) of the fire data in Pausas and Fernández-Muñoz (2012). Because of a significant fire-regime shift during the 1970s, we split the Valencia data into two periods: 1880-1970 (pre-1970s; fuel-limited fire regime) and 19752014 (post-1970s; drought-driven fire regime). The comparison of fire regimes between the Rif and both periods in Valencia was conducted under the hypothesis that the Rif fire regime should resemble that of Valencia in the pre-1970s. Because detailed fire statistics for the Rif were available for only eight years, we also used eight years (randomly selected) for Valencia and for each period (pre- and post-1970s). This random selection was performed
20 times to estimate the variability of fire activity in Valencia. Differences between the Rif and Valencia were assessed by looking at whether the Rif data fall within the interval of variability of the Valencia data for each period.

\section{RESULTS}

\section{Fire Regime in the Western Rif}

During the period 1988-2015, 3803 fires burned a total of 41,641 ha $(3.29 \%$ of the total area of the western Rif). On average, 136 fires burned 1487 ha yearly, although fire activity exhibited considerable yearly variation (Figure S3). The number of fires increased during the 1988-2015 period, whereas no temporal pattern was found with the total burnt area (Table 2, Figure S4). For the same period, the average maximum temperature significantly increased from around $22-24^{\circ} \mathrm{C}$, and the annual rainfall tended to decrease, although the correlation was not significant due to the strong interannual variability (Table 2, Figure S4). Consequently, the number of annual fires recorded in the Rif increased with the average maximum temperature and decreased with annual rainfall (Table 2, Figure S5). The annual area burnt was not related to the average maximum temperature, but significantly diminished with the annual rainfall (Table 2, Figure S5).

During the period 2008-2015, 1182 fires burned approximately 7443 ha. This represents $0.6 \%$ of the total study area, or $1.9 \%$ of the vegetated area (including natural vegetation and monocultures). The number of fires was strongly biased towards small fires, with only one fire larger than 1000 ha (Sidi BouHaja, 1480 ha; Table 3). Most fires (73.6\%) and most (94\%) of the burnt area occurred during the hottest period, from June to 
Table 3. Number of Fires and Area Burnt for Each Fire Size Class in the Western Rif for the Period 20082015.

\begin{tabular}{lcccc}
\hline Fire size class (ha) & Number of fires & \% of fires & Area burnt (ha) & \% of area burnt \\
\hline $0-1$ & 833 & 70 & 244 & 3 \\
$1-10$ & 287 & 24 & 894 & 12 \\
$10-100$ & 49 & 4 & 1606 & 22 \\
$100-1000$ & 12 & 1 & 3219 & 43 \\
$>1000$ & 1 & 0 & 1480 & 20 \\
\hline
\end{tabular}
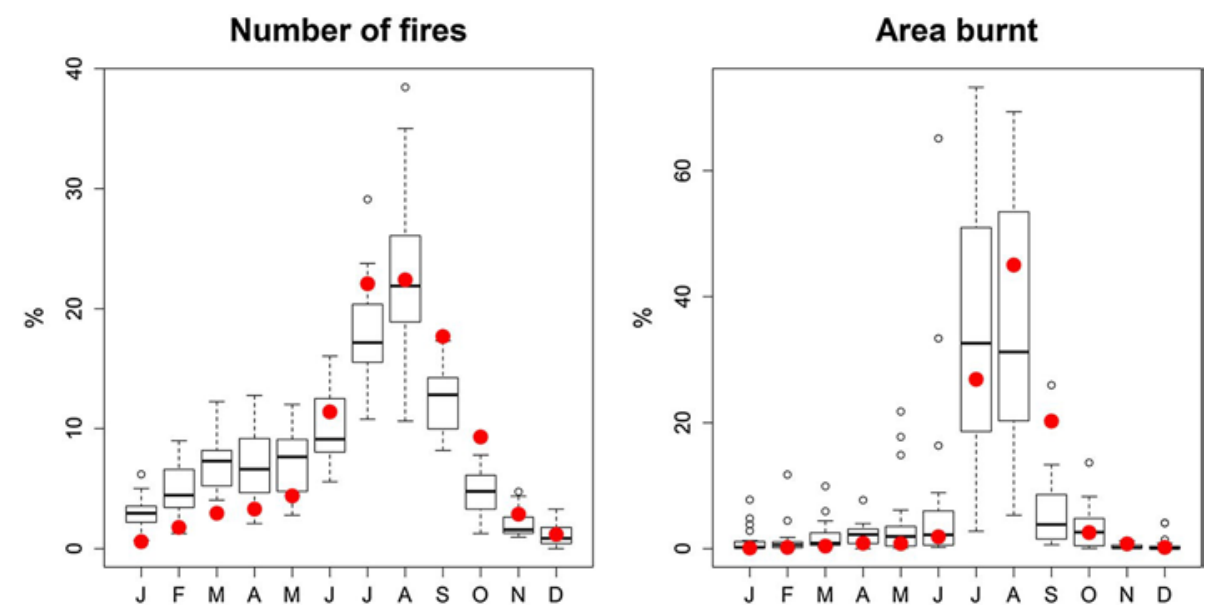

Figure 2. Monthly proportion of fires (left) and area burnt (right) in Valencia (boxes) and in the western Rif (red symbol). Boxes show the variability of 20 randomly chosen 8 years in Valencia (1880-2014), and symbols the 8 years of available data in the Rif (2008-2015).
September, and especially in July and August (Fig. 2; Figure S6).

Most of the burnt area during the period 20082015 belonged to only two land-use types (Table 4), namely natural forests of cork oak Quercus suber (39.9\%) and coniferous plantations (45.9\%). Both land-use types are among the commonest land-use types in the western Rif (Figure S7). Excluding the non-forested area, the proportion of burnt area significantly differed from the expectation based on the extension of each land-use type (Table 4) in such a way that coniferous plantations were burnt more frequently than expected by chance (highest residuals), followed by cork oak forest. Shrubland burned less than expected (lowest residuals, Table 4). Similarly, the burnt area differed among bioclimates, with perhumid and humid zones more burnt than expected by their areas (high residuals), and sub-humid zones less burnt than expected (low residuals, Table 4).

\section{Comparison with the Valencia Region}

The seasonal distribution of fires was very similar between Rif and Valencia and concentrated in the hottest and driest period from July to September (Fig. 2). These two regions also showed a similar trend in annual climate changes: a significant in- crease in the average annual temperature, and a slight decline in rainfall (but not significant due to the high interannual variability; Table 2). These figures suggest that the two regions share similar climate dynamics. In both regions, the burnt area was negatively related to precipitation, although this relation was especially weak in the Rif (Table 2).

Regarding the distribution of fire size classes, fire data on the Rif fall within the interval of variability of the pre-1970s in Valencia-but not within the range of the post-1970s fire regime (Fig. 3). Hence, the current fire regime in the Rif resembles that of Valencia in the period when fires were smaller and fuel-limited (prior to the 1970s).

\section{DISCUSSION}

Like other Mediterranean climate regions, the Rif is characterized by frequent fires concentrated in the hottest and driest period of the year. Moreover, the region shows a trend of rising temperatures and a weak tendency of diminishing in rainfall during the recent decades; this follows the climate patterns observed in other regions of the Mediterranean Basin (Pausas 2004; Mariotti and others 2008; Lelieveld and others 2012). The recent increase in the number of fires in the Rif (Figure S4) is also similar 
Table 4. Total Extent and Area Burnt of Each Land-Use and Bioclimatic Type on the Western Rif for the Period 2008-2015.

\begin{tabular}{|c|c|c|c|c|c|c|}
\hline \multirow[b]{2}{*}{ Classes } & \multicolumn{2}{|l|}{ Area } & \multirow[t]{2}{*}{ Number of fires } & \multicolumn{3}{|c|}{ Area burnt } \\
\hline & ha & $\%$ & & ha & $\%$ & residuals \\
\hline \multicolumn{7}{|l|}{ Land-use types } \\
\hline Pinus pinaster & 8200 & 0.7 & 9 & 21 & 0.26 & -10.75 \\
\hline Quercus suber & 114,670 & 9.2 & 195 & 2965 & 2.59 & 21.42 \\
\hline Quercus rotundifolia & 24,200 & 1.9 & 42 & 396 & 1.64 & 2.61 \\
\hline Other natural forests & 23,985 & 1.9 & 50 & 91 & 0.38 & -17.33 \\
\hline Scrubland & 163,524 & 13.2 & 155 & 418 & 0.26 & -61.92 \\
\hline Coniferous plantations & 49,124 & 4.0 & 565 & 3415 & 6.95 & 88.46 \\
\hline Other monocultures & 14,462 & 1.2 & 87 & 92 & 0.64 & -10.98 \\
\hline Non-forested & 844,335 & 68.0 & 79 & 41 & 0.005 & \\
\hline \multicolumn{7}{|l|}{ Bioclimatic type } \\
\hline Perhumid & 150,301 & 7.3 & 203 & 1287 & 0.86 & 32.89 \\
\hline Humid & 597,879 & 29.2 & 643 & 3638 & 0.61 & 37.29 \\
\hline Sub-humid & $1,223,461$ & 59.8 & 276 & 2141 & 0.17 & -54.60 \\
\hline Semi-arid & 74,360 & 3.6 & 60 & 377 & 0.51 & 6.59 \\
\hline
\end{tabular}

For each type, the extent in hectares ( $h a)$ and the percentage (\%) are included. Standardized residual sof the Chi-squared test for the distribution of areaburnt in the different land uses (v2 = 9958, $d f=6, P<0.0001$ ) and bioclimatic types (v2 $=3227, d f=3, P<0.0001$ ) are included.

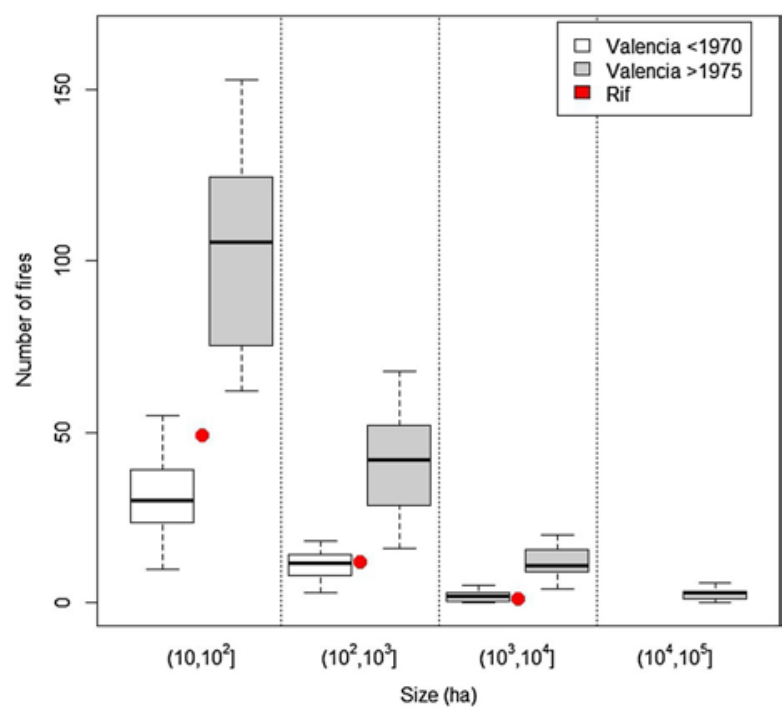

Figure 3. Fire size distribution in Valencia, for the period 1880-1970 (white boxes) and for the period 1975-2014 (grey boxes), and in the western Rif (red symbols, 20082015). Boxes show the variability of 20 randomly chosen 8 years in Valencia for each period, and symbols (dots) show the 8 years of available data in the Rif. The cumulative form of this figure is shown in Figure S8.

to what is occurring elsewhere in the Mediterranean Basin (Pausas 2004; Gouveia and others 2016) and is likely to be driven by the growing human population (for example, from 150 to 215 inhabitants $/ \mathrm{Km}^{2}$ from 1994 to 2010 in the Chefchaouen valley; RGPH 2005; Taiqui 2005). For instance, new roads in the Rif are enabling access to remote areas where people burn forest areas to clear land for cannabis cultivation (Gatchui and others 2014). Despite the recent increase in the number of forest fires in the Rif (Table 2, Figure S3, S4), the annual burnt area in this region (on average, $0.210 \%$ of the forest land for 2008-2015; $0.336 \%$ for $1988-2015$ ) is still low compared with climatically similar regions of the European rim of the basin (for example, Gonza' lez and Pukkala 2007; Mateus and Fernandes 2014; Koutsias and others 2012; San-Miguel-Ayanz and others 2013). In fact, fires in the Rif region are smaller than fires in Valencia (Mediterranean Europe; Fig. 3) and match better with the fire regime in European Mediterranean countries during the period in which the rural population was large (for example pre-1970s in Spain; Pausas and Fernández-Muñoz 2012). This suggests that fire regimes in the Rif are fuel-limited and climate is less relevant. Although the Rif has similar population density to some European regions, the socioeconomic trends and human spatial distribution is very different: in the Rif the population is highly rural with many livestock and fuel gathering activities (Taiqui 2005), rural landscapes in southern Europe have been dramatically depopulated in recent decades, and people have concentrated in cities and engaged in urban activities (Preiss and others 1997; Pinilla and others 2008; Pausas and Fernández-Muñ oz 2012). This rural depopulation caused a shift in the fire 
regime due to land abandonment and the greater amount and connectivity of fuel in the landscape (Pausas and Fernández-Muñoz 2012; Pausas 2004). Because the rural depopulation was so drastic that it has had consequences for the landscape, this demographic shift has been called it a collapse of the rural lifestyle (Pausas and Keeley 2014). Our results suggest that the fire-regime shift observed over time in the European rim (Pausas and Fer- ná ndez-Muñ oz 2012) mirrors the spatial variation now observed between the two rims of the Mediterranean Basin. This does not mean that fires in the Rif are independent of fuel, that is, different land covers have differing flammability, and when fires do occur in the Rif, they tend to be more concentrated in coniferous plantations and cork oak woodlands, and less in shrubland (which tends to be overgrazed). In Morocco, coniferous plantations are predominantly Pinus pinaster (Destremau 1974; Destremau and others 1976; Pastuszka and Sabay 1997), a highly flammable pine species (Shakesby and others 1996; Bremer and Farley 2010). Cork oak forests grow on poor soil and have a heathy flammable understory, which the locals tend let burn to transform the land for agriculture or grazing (including the expanding cannabis cultivation; Pastor-López and others 1997; Lara and others 2015). This is driving a severe reduction in these forests (for example, in the Ketama region the forested area shrunk from around 8000 ha in 1984 to only about 500 ha in 1990; Benabid 2000; Figure S9). Overgrazing and land transformation to production systems are no longer the dominant processes in Mediterranean Europe.

Overall, there is evidence that the current fireregime differences between the Rif and Valencia are driven by contrasting socioeconomic conditions (that is, very different rural and urban population densities; Table 1). However, the two regions do not have identical climate, and thus, we cannot rule out that some differences are due to differing environmental conditions. For instance, the Rif is slightly more southerly (warmer) than Valencia and has less summer rainfall (which could limit fuel and fire size); however, the Rif has some Atlantic influence with wetter winters and higher annual rainfall than Valencia. Thus, it is not easy to predict the differences between Valencia and Rif in water availability for vegetation during the fire season. In addition, fires are biased towards relatively moister regions of the Rif (Table 4; Benabid 2000), suggesting that fire size is unlikely to be limited by aridity. That is, despite climate exerting some influence on the fire regimes (for example, a weak effect in the temporal variability; Figure S5), the main driver limiting fire size and area burnt is fuel, and thus, current fire regimes are more fuellimited than drought-driven.

On the basis of the experience from the European rim, we could attempt to predict fire-regime shifts for the southern rim (space-for-time substitution; Pickett 1989). Tourism is likely to expand in northern Africa, and the construction industry will grow along the coast (Belghazi 2014). This will have consequences for coastal biodiversity and will also encourage the human displacement from rural to coastal areas. Consequently, the rural lifestyle could collapse, as happened in European regions, with the consequent accumulation of fuels inland (increasing amount and continuity) and the abrupt rise of an era of megafires (Pausas and Ferna' ndezMuñoz 2012; Tedim and others 2013; Gouveia and others 2016). We cannot easily make a forecast concerning when this will happen, as this process has occurred in many places but at different times depending of socioeconomic dynamics. For instance, the shift from fuel-limited to drought-driven fire regimes occurred in the 1970s in Spain (Pausas and Fernández-Muñoz 2012), in the 1980s in Greece (Stamou and others 2016), and in the 1990s in the former Soviet Union (Dubinin and others 2011). Rural population density in the Rif is currently of 0.92 inhab./ha, and a collapse can be estimated to occur before decreasing to 0.6 inhab./ ha (Pausas and Fernández-Muñoz 2012). Thus, monitoring rural populations might provide an early warning as the fire-regime shift will follow a few years after the collapse of the rural population (Pausas and Fernández-Muñoz 2012). In fact, the depopulation of rural areas has already started in some North African regions such as in Algeria (driven by security problems), and in parallel, fuel and fire activity are now on the rise (Bessaoud 2006; Delenda 2012).

Overall, temporal and spatial variability in fire regimes across the Mediterranean Basin is strongly influenced by the human factor, which is determined by local socioeconomics (Bowman and others 2011; Pausas and Keeley 2014; Seijo and others 2017). This is because in highly populated regions such as the Mediterranean Basin, human activities directly affect ignition patterns, the amount and continuity of vegetation (fuels), and the fire suppression efforts (Vega-Garci'a and Chuvieco 2006; Loepfe and others 2010; Pausas and Paula 2012). Climate is also important, but especially when fuels are not limiting fires (for example, Pausas and Fernández-Muñoz 2012; Gouveia and others 2016). Current socioeconomic and climatic changes point to an increasing role for climate in 
the future, as rural populations continue to fall in the Mediterranean Basin while climate warms. The strong dependence on fuels, however, also implies that management could potentially shape fire regimes.

\section{ACKNOWLEDGEMENTS}

The authors would like to thank HCEFLCD and ENFI for providing fire information for the Rif and the Spanish government for the fire data of Valencia. This work has been performed under the framework of the PROMETEO/2016/021 project from Generalitat Valenciana.

\section{REFERENCES}

Ajbilou R. 2001. Biodiversidad de los bosques de la pen'insula Tingitana Marruecos. PhD dissertation, Sevilla: University of Sevilla.

Bessaoud O. 2006. La straté gie de dé veloppement rural en Algé rie. Politiques de dé veloppement rural durable en Mé diterrane' e dans le cadre de la politique de voisinage de l'Union Europe' enne. In: J.P. Chassany, J.-P. Pellissier. Eds. Options Mé diterrané ennes: Série A. Séminaires Méditerrané ens 71, pp 79-89.

Benabid A. 1982. Etudes Phytoe' cologique, Bioge' ographique et Dynamique des Associations et $\mathrm{Se}^{\prime}$ ries Sylvatiques du Rif Occidental MAROC, The`se de Doc. Es. Sc., FST. St. Je' rome, Marseille, France.

Benabid A. 2000. Flore et é cosyste` me du Maroc: é valuation et pré servation de la biodiversite' . Paris: Ibis Press.

Belghazi S. 2014. Etude d'evaluation socio-é conomique des activite' s de la Mer et du Littoral Mé diterrane' en au Maroc. Sustainable Governance and Knowledge Generation. Final Report. Global Environmental Facility \& the World Bank. GEF ID 4001.

Bond WJ, Woodward FI, Midgley GF. 2005. The global distribution of ecosystems in a world without fire. New Phytol 165:525-38.

Bowman DMJS, Balch J, Artaxo P, Bond WJ, Cochrane MA, D’Antonio CM, DeFries R, Johnston FH, Keeley JE, Krawchuk MA, Kull CA, Mack M, Moritz MA, Pyne S, Roos CI, Scott AC, Sodhi NS, Swetnam TW. 2011. The human dimension of fire regimes on Earth. J Biogeogr 38:2223-36.

Bremer LL, Farley KA. 2010. Does plantation forestry restore biodiversity or create green deserts? A synthesis of the effects of land-use transitions on plant species richness. Biodivers Conserv 19:3893-915.

Covington WW, Moore MM. 1994. Southwestern Ponderosa forest structure: changes since Euro-American settlement. J For 92:39-47.

Delenda A. 2012. 1962-2012, cinquante ans de recherche démographique en Algérie. Al-Mawaqif 7:1-16.

Destremau DX. 1974. Pré cisions sur les aires naturelles des principaux conifers marocains en vue de l'individualisation de provenances. Annales de la Recherche Forestie`re au Maroc 14:3-90.

Destremau D, Jolly H, Tafri T. 1976. Contribution àla connaissance des provenances de Pinus pinaster. Annales de la Recherche Forestie`re au Maroc 16:101-53.
Dubinin M, Luschekina A, Radeloff VC. 2011. Climate, livestock, and vegetation: what drives fire increase in the arid ecosystems of southern Russia? Ecosystems 14:547-62.

Gatchui HCH, Smektala G, Solan D, Taiqui L, Ngomeni AF. 2014. Cannabis cultivation and deforestation in the Site of Bio Ecological Interest SIBE of Bouhachem, Morocco. Int J Biol Chem Sci 3:1179-91.

Gil L, Lopez R, Garcia-Mateos A, Gonzalez-Doncel I. 2009. Seed provenance and fire-related reproductive traits of Pinus pinaster in central Spain. Int J Wildland Fire 18:1003-9.

Gonza' lez JR, Pukkala T. 2007. Characterization of forest fires in Catalonia north-east Spain. Eur J For Res 126:421-9.

Gouveia CM, Bistinas I, Liberato MLR, Bastos A, Koutsias N, Trigo R. 2016. The outstanding synergy between drought, heatwaves and fuel on the 2007 Southern Greece exceptional fire season. Agric For Meteorol 218-219:135-45.

Kasischke ES, Turetsky MR. 2006. Recent changes in the fire regime across the North American boreal region: spatial and temporal patterns of burning across Canada and Alaska. Geophys Res Lett 33:L0970.

Keeley JE. 2002. Native American impacts on fire regimes of the California coastal ranges. J Biogeogr 29:303-20.

Keeley JE, Bond WJ, Bradstock RA, Pausas JG, Rundel PW. 2012. Fire in Mediterranean climate ecosystems: ecology, evolution and management. Cambridge: Cambridge University Press.

Koutsias N, Arianoutsou M, Kallimanis AS, Mallinis G, Halley JM, Dimopoulos P. 2012. Where did the fires burn in Peloponnisos, Greece the summer of 2007? Evidence for a synergy of fuel and weather. Agric For Meteorol 156:41-53.

Lara EL, Däide H, Chaouki M. 2015. Cannabis cultivation and depleted forest areas in the province of taounate Rif southern, morocco: landscape and economic repercussions. Bolet'in de la Asociación de Geógrafos Espanoles 68:473-6.

Lelieveld J, Hadjinicolaou P, Kostopoulou E, Chenoweth J, El Maayar M, Giannakopoulos C, Hannides C, Lange M, Tanarhte M, Tyrlis E, Xoplaki E. 2012. Climate change and impacts in the eastern Mediterranean and the middle east. Clim Change 114:667-87.

Loepfe L, Martínez-Vilalta J, Oliveres J, Piñol J, Lloret F. 2010. Feedbacks between fuel reduction and landscape homogenisation determine fire regimes in three Mediterranean areas. For Ecol Manag 259:2366-74.

Mairota P, Thornes J, Geeson N. 1998. Atlas of Mediterranean environments in Europe: the desertification context. Chichester: Wiley.

Mariotti A, Zeng N, Yoon J-H, Artale V, Navarra V, Alpert P, Li LZX. 2008. Mediterranean water cycle changes: transition to drier 21st century conditions in observations and CMIP3 simulations. Environ Res Lett 3:044001.

Marlon JR, Bartlein PJ, Carcaillet C, Gavin DG, Harrison SP, Higuera PE, Joos F, Power MJ, Prentice IC. 2008. Climate and human influences on global biomass burning over the past two millennia. Nat Geosci 1:697-702.

Mateus P, Fernandes PM. 2014. Forest fires in Portugal: dynamics, causes and policies. In: F. Reboredo Ed forest context and policies in Portugal, present and future challenges World Forests 19, pp 97-115.

McKenzie D, Gedalof ZM, Peterson DL, Mote P. 2004. Climatic change, wildfire, and conservation. Conservation Biology 18:890-902. 
Meddour-Sahar O, Gonza' lez Caba' n A, Meddour R, Derridj A. 2013b. Wildfire management policies in Algeria: present and future needs. Public policies national and international level and the wildland fire management problem. In Proceedings of the Fourth International Symposium on Fire Economics, Planning, and Policy: Climate Change and Wildfires, Mexico City, Mexico.

Mharzi Alaoui H, Assali F, Rouchdi M, Lahssini S, Tahiri D. 2015. Analyse de l'interaction entre l'e' closion des feux de fore $^{\wedge}$ ts et les types de bioclimat au Nord du Maroc_-cas de la re' gion du Rif occidental. Revue Marocaine des Sciences Agronomiques et $\mathrm{Ve}^{\prime}$ te' rinaires 3:46-53.

Mikesell MW. 1960. Deforestation in Northern Morocco. Science 132:441-8.

Moreira F, Russo D. 2007. Modelling the impact of agricultural abandonment and wildfires on vertebrate diversity in Mediterranean Europe. Landsc Ecol 22:1461-76.

Moreira F, Viedma O, Arianoutsou M, Curt T, Koutsias N, Rigolot E, Barbati A, Corona P, Vaz P, Xanthopoulos G, Mouillot F, Bilgili E. 2011. Landscape-wildfire interactions in southern Europe: implications for landscape management. J Environ Manag 92:2389-402.

Naveh Z. 1975. The evolutionary significance of fire in the Mediterranean region. Vegetatio 29:199-208.

Pastor-López A, Taiqui L, Bouziane H, Riadi H, Martín JM. 1997. Structure of Quercus suber forests in Chefchaouen basin NE. Morocco. Implications on management at a landscape scale. Mediterranea Serie de Estudios Biológicos 16:65-76.

Pastuszka P, Sabay H. 1997. Strate' gie d'ame' lioration du pin maritime au Maroc. Actes du Sé minaire sur l'ame' lioration, laconservation et l'utilisation des ressources gé né tiques forestie`res Marocaines. Annales de la Recherche Forestie`re au Maroc 1997:92-103.

Pausas JG, Vallejo VR. 1999. The role of fire in European Mediterranean ecosystems. In: Chuvieco E, Ed. Remote sensing of large wildfires in the European Mediterranean basin. New York: Springer-Verlag. p 3-16.

Pausas JG. 2004. Changes in fire and climate in the eastern Iberian Peninsula Mediterranean Basin. Clim Change 63:33750.

Pausas JG, Keeley JE. 2009. A burning story: the role of fire in the history of life. BioScience 59:593-601.

Pausas JG, Fernández-Muñoz S. 2012. Fire regime changes in the Western Mediterranean Basin: from fuel-limited to drought-driven fire regime. Clim Change 110:215-26.

Pausas JG, Paula S. 2012. Fuel shapes the fire-climate relationship: evidence from Mediterranean ecosystems. Glob Ecol Biogeogr 21:1074-82.

Pausas JG, Ribeiro E. 2013. The global fire-productivity relationship. Glob Ecol Biogeogr 22:728-36.

Pausas JG, Keeley JE. 2014. Abrupt climate-independent fire regime changes. Ecosystems 17:1109-20.

Pezzatti GB, Zumbrunnen T, Bürgi M, Ambrosetti P, Conedera M. 2013. Fire regime shifts as a consequence of fire policy and socioeconomic development: an analysis based on the change point approach. For Policy Econ 29:7-18.

Pinilla V, Ayda MI, Saez LA. 2008. Rural depopulation and the migration turnaround in Mediterranean Western Europe: A case study of Aragon. J Rural Commun Dev 3:1-22.

Piñol J, Terradas J, Lloret F. 1998. Climate warming, wildfire hazard, and wildfire occurrence in Coastal Eastern Spain. Clim Change 38:345-57.
Pickett STA. 1989. Space-for-time substitution as an alternative to long-term studies. Likens GE editor. Long-Term Studies in Ecology: Approaches and Alternatives. New York, NY: Springer New York, p 110-135.

Preiss E, Martin JL, Debussche M. 1997. Rural depopulation and recent landscape changes in a Mediterranean region: consequences to the breeding avifauna. Landsc Ecol 1:51-61.

Quézel P, Médail F. 2003. Écologie et biogeographie des forêts du bassin méditerrané en. Paris: Elsevier.

Salis M, Ager AA, Arca B, Finney MA, Bacciu V, Duce P, Spano D. 2013. Assessing exposure of human and ecological values to wildfire in Sardinia, Italy. Int J Wildland Fire 22:549-65.

San-Miguel-Ayanz J, Moreno JM, Camia A. 2013. Analysis of large fires in European Mediterranean landscapes: lessons learned and perspectives. For Ecol Manag 294:11-22.

Schmuck G, San-Miguel-Ayanz J, Camia A, Durrant T, Boca R, Whitmore C, Liberta` G, Corti P, Schulte E. 2012. Forest Fires in Europe, Middle East and North Africa 2011 EUR 25483 EN. Luxemburg: Publications Office of the European Union; 2012. JRC74152.

Seijo F, Millington JDA, Gray R, Mateo LH, Sangüesa-Barreda G, Camarero JJ. 2017. Divergent fire regimes in two contrasting mediterranean chestnut forest landscapes. Hum Ecol 45:20519.

Shakesby RA, Boakes DJ, de OA Coelho C, Gonc, alves AJB, Walsh RPD. 1996. Limiting the soil degradational impacts of wildfire in pine and eucalyptus forests, Portugal: comparison of alternative post-fire management practices. Appl Geogr $16: 337-56$

Stamou Z, Xystrakis F, Koutsias N. 2016. The role of fire as a long-term landscape modifier: Evidence from long-term fire observations 1922-2000 in Greece. Appl Geogr 74:47-55.

Swetnam TW. 1993. Fire history and climate change in giant sequoia groves. Science 262:885-9.

Taiqui L, Martin CC. 1997. Élé ments historiques d'analyse é cologique des paysages montagneux du Rif Occidental Maroc. Mediterrá nea. Serie de Estudios Bioló gicos 16:23-35.

Taiqui L. 2005. Evolution ré cente de la structure du paysage du bassin de Chefchaouen 1958-1986. Mutations des milieux ruraux dans les montagnes rifaines Maroc. Rif GRG, editor. Sé rie Etudes Spatiales 2, Faculte' des Lettres \& Sciences Humaines de Tétouan.

Tedim F, Remelgado R, Borges C, Carvalho S, Martins J. 2013. Exploring the occurrence of mega-fires in Portugal. For Ecol Manag 294:86-96.

Trabaud L. 1996. Effects of fire frequency on plant communities and landscape pattern in the Massif des Aspres Southern France. Landsc Ecol11:215-24.

Vega-Garc' 1a C, Chuvieco E. 2006. Applying local measures of spatial heterogeneity to Landsat-TM images for predicting wildfire occurrence in Mediterranean landscapes. Landsc Ecol 21:595-605.

Verdú M, Pausas JG. 2007. Fire drives phylogenetic clustering in Mediterranean Basin woody plant communities. J Ecol 95:1316-23.

Westerling AL, Hidalgo HG, Cayan DR, Swetnam TW. 2006. Warming and earlier spring increases Western U.S. Forest Wildfire Activity. Science 313:940.

Zohry A. 2005. Migration without Borders: North Africa as a reserve of cheap labour for Europe. Migration without Borders Series, Paris: UNESCO. 